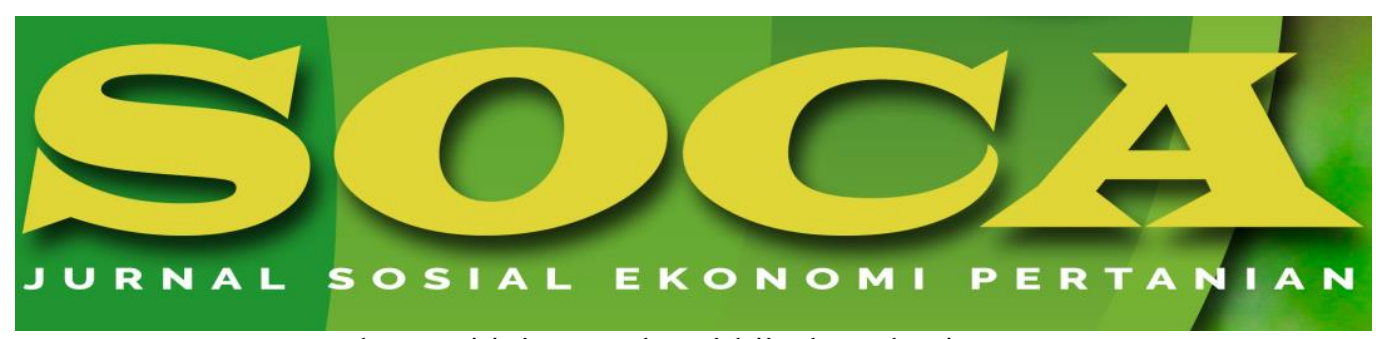

https://ojs.unud.ac.id/index.php/soca

\title{
National Strategy And Policy On The Agricultural Sector During The Covid-19 Outbreak
}

\author{
Supardi Rusdiana and Chalid Talib \\ Indonesian Research Institute of Animal Production, PO.Box. 221. Ciawi-Bogor \\ E-mail: s.rusdiana20@gmail.com \\ Mobile : 081282010532
}

Submitted: June 10th, 2020; Revised: June 15th, 2020; Accepted: June 20th 2020

\begin{tabular}{l}
\hline \\
\hline Keywords: \\
Impact; Social; \\
Economy; \\
Covid-19; \\
Agricultural \\
Sector
\end{tabular}

\section{Abstract}

The spread of Covid-19 majorly affected the global economic stability. This major change also changed the dynamic of Indonesia economic growth. This study employed a literature study and discussion technique to analyze the situation during the spread of Covid-19. The data collected from the literature, websites, national and international news that relevant to the recent policies and conditions. This study aimed to know the strategy and policy taken by the national policymaker in the agricultural sector during the Covid-19 outbreak. Results showed that the impact of the spread of Covid-19 on the economic aspect and the strategy chosen depending on the national policies. The national policies made based on various aspects, risks, and market scenarios. The labor-intensive effort, development of the agricultural technology, and marketing efforts intensively done to engage the farmer and consumer. The long-term policies strengthen the national food security and agricultural sector. The policies of data use arranged to be applied in various sectors, especially agricultural and food security. These policies managed to encourage and accelerate the synergy of a sustainable agricultural modernization. The national food security development actively contributed to cope with the food security gap in all area in Indonesia. The long-term policies provided a better comprehension and behavior change toward the farmer wellness aspect. 
How to Cite (APA 6 ${ }^{\text {th }}$ Style):

Rusdiana, S., \& Talib, C. (2020). National Strategy And Policy On The Agricultural Sector During The Covid-19 Outbreak. SOCA: Jurnal Sosial Ekonomi Pertanian, 14(3), 572 - 590.

https://doi.org/10.24843/SOCA.2020.v14.i03.p17

\section{INTRODUCTION}

In the first quarter of 2020, Corona Virus Disease 2019 (Covid-19) attacked the world. This outbreak started in Tiongkok, especially in Wuhan City (Hermanto, 2020). Some countries, such as China, Italy, Saudi Arabia, and other countries applied lockdown measures in their area. Indonesia has taken fast action to manage the outbreak after the World Health Organization (WHO) declared Covid-19 as a global outbreak (Sohrabi et al., 2020). There were at least 199 countries that were infected with a total of 7.4 million positive and 0.42 million people died per June 10th, 2020 (Johns Hopkins CSSE, 2020). The sudden change in consumer behavior in the form of panic buying repressed the IDR exchange rate toward the USA dollar. The quarantine measure in small and wide range also conducted to reduce the transmission of the Covid-19. This outbreak widely affected all aspects of life, most of the world societies was losing their job due to the quarantine measures. This was a major issue and proper management required to be taken by the national stakeholder to deal with this issue.

The worker in the informal sector highly depended on their daily salary. Quarantine measures made them found major difficulties in meeting their daily need to survive. The impact of Covid-19 on the economic aspect was quite massive. The quarantine measures in land, water, and air area on the local or international scale caused stagnant economic growth in all sectors. Most factories located in the United State of America (USA), Europe, and Australia were instructed to be closed during the Covid-19. This situation affected the low productivity due to the low demand and low usage of transportation, especially for the import and export requirement (Wikipedia, 2020, McGhee, 2020, Byrne, 2020). This resulted in a high rate of unemployment. The global economic growth was getting worse during the spread of the Covid-19 outbreak (Ozili et al., 2020). The low level of worker productivity also happened in Indonesia. There was also a high number of unemployment and low transportation usage. These things massively affected the slow economic growth in Indonesia. The economic growth this year was very low in comparison with the previous year (Sohrabi 2020; Susanti, 2020). The massive decline happened in all sectors, including agriculture and animal husbandry.

The other impact was the low exchange rate of IDR to other currencies due to the high prices of imported raw material for the staple food industry (Guntoro, 2020). The Center of Reform on Economics (CORE) predicted that Indonesia economic growth would be reached 2\%-3\% in the year 2020 (Hermanto, 2020). In some countries, the community was buying a high number of staple food to be stocked. The affected-countries created specific policies to manage the impact of Covid-19. These policies directed to decrease the number of unemployed communities, improve the transportation used, and increasing the utilization of productive workers. The national stakeholder required to create, legalize, and 
implement the policies through the minister, agency, educational institution, and community organization to work together to prevent the spread of Covid-19. The utilization of information and communication technology helped the government in providing valid and completed data as a reference to the public policies (Gadjah Mada University, 2020).

The policies made was the quarantine measures. These policies were limiting the activity of working, studying, traveling, and socializing (Mardiyah \& Nunung, 2020). These policies also known as local/areas lockdown or physicalsocial distancing. The community also instructed to use a mask if they have to do some activities outside their house. The community also forbid to be gathered in a place. This measures officially implemented in the middle of March 2020 and extended as social-distancing on a wider scale in some areas in Indonesia. These policies implemented in all sectors, especially the health and agricultural sectors as the front line in managing the outbreak impact. Djufry (2020) suggested to maintain and improve the economic growth through two approaches: (1) resources management in the rural and city area and (2) improving the added-value by conducting a synergy and integrated strategy between sectors (staple food industry, agricultural sector, processing industry, tourism activities, creative digital and small business entity that linked the farmer and product processor to consumer).

The well-organized collaboration between sectors was a strategy offered to manage the change that happened due to the Covid-19 outbreak, especially on the national economic growth. The Indonesia Ministry of Agricultural through the Directorate General of Animal Husbandry and Health coordinated the staple food demand (meat, egg, and milk), the Directorate General of Staple Food coordinated the staple food commodity need, and the Directorate General of Plantation coordinated the granulated sugar and cooking oil demand (factories and traders). The goal was to improve and maintain national food security through human resource empowerment and the improvement of human resources to decrease and prevent the spread of Covid-19, staple food needs, and sustainable agricultural sector development. The specific aid for the agricultural field was the aid for the production and skill/passion in agricultural entrepreneurship especially for the farmer and the millennial generation to utilize the market chance and novel agricultural commodity.

The economic stimulus in the form of social aid especially for the human resources in the city and rural areas in the short-term period required to slow the decrease of macroeconomic, sector, and the impact on the household to the social environment before the stable economic growth. On the social and economic aspect, multi-channel communication, information, and education about the healthy lifestyle during the Covid-19 Outbreak must be disseminated to the farmer and some figure in the agricultural sector. The availability of some infrastructures and staple food also must be ensured to secure the community demand. Therefore, this study aimed to know the strategy and policy in the agricultural sector during the Covid-19 outbreak. 


\section{RESEARCH METHODS}

This study employed a literature study and discussion technique. All data elaborated in this study were gathered through relevant literature such as information/websites, national and international news during the Covid-19 outbreak in Indonesia. Data gathered was assured to be relevant to the current situation. The data analyzed to know the impact of the Covid-19 on the social, economic stability, food security, agricultural sector, and appropriate solution for the issue. The study result then combined with the national policies that associated with the agricultural sector and Covid-19. These national policies meant to improve the national economic stability that would finally contributed to the community purchasing power through a synchronized cross-sector development. An improvement in the business sector was also becoming a goal of these policies. Some private business was experiencing a drastic decline during the outbreak. This study also elaborated strategies required to improve the economic value through agribusiness proper development.

The variables calculated in this study were the surplus/deficit, staple food availability, and staple food need. The model of the global economic impact due to the Covid-19 outbreak used was taken from a study done by (Laurence, 2020) and (Rob et al., 2020). The secondary data (Food Security Department of Agricultural Ministry, National Institute of Statistic Data, etc.) applied to produce stronger and more precise results. Hence, relevant analysis could be elaborated and concluded specifically according to the current situation. The impact on the economic field only happened in a short-term period which could be directed to improve the economic aspect of the agricultural field in a long-term period. Therefore, the analysis of the impact of the spread of Covid-19 on the economic stability and the strategies used to improve the economic values in the agricultural and non-agricultural field must be involved some criteria: (1) The prediction of availability, production, strategic staple food need in 2020 (2) economic growth in Indonesia and acceleration of government investment in encouraging the progress of agricultural and livestock business. Empirically, the data gained and supported by the secondary sources which indicated that the data could be updated and fluctuating due to the current situation

\section{RESULTS AND DISCUSSION Indonesia Economic Growth}

The national economic growth in the first quarter in 2020 was $2.97 \%$ year-onyear; this growth was decreasing as much as 2.41\% in the year 2019 (Suhariyanto, 2020). The national growth in the first quarter of 2020 was lower than the first quarter in 2019 (5.07\%) and the fourth quarter in 2019 (4.97\%). The stagnant economic growth in Indonesia was majorly affected by China and USA national growth. Indonesia main export destination was China. The export volume to China was $15 \%$ of the total export, while the total export in the quarter of 2020 was decreasing (6.8\%). Indonesia second export destination was the USA. The export volume was growing up to $0.2 \%$. While the export volume to the Singapore and South Korea was relatively slow with the percentage of $1.3 \%$. The economic growth in Indonesia was highly affected by China economic growth. If China economic growth 
was slowing as much as $1-2 \%$, the Indonesian economic growth would be slowing to 0.1-0.3\% (Hadiutomo, 2020).

Mahardhika (2020) from the Center for Indonesian Policy Studies (CIPS) predicted that Indonesia potentially had a stable economic growth if able to choose proper policies for the current condition. All parts of the community must actively participate in the national effort to improve the national economic growth. Anticipation for some factors that potentially growing as factors that inhibiting economic growth. The action taken toward this issue could be reflected by the policies in 2019. At that time, the national economic growth was only reaching $5.02 \%$, which was lower than the economic growth on the 2018 (5.17\%) (Mahardhika, 2020). This stagnant economic growth happened due to the trade war between the USA and China. In 2020, the low number of products from and to China happened due to the measures to close some factories because of the Covid-19 outbreak. This situation affected China economic growth, which also affected global economic growth.

The staple industry growth in Indonesia usually increases two times higher than the prior growth ( $7 \%$ to $14 \%$ in a year). The economic growth in Indonesia in 2020 was far to be concluded, but Hadiutomo (2020) predicted that the current national economic growth would be similar to the national economic growth in 2020 . Therefore, this situation indicated that the spread of Covid-19 didn't affect all types of trade, agricultural products, and non-agricultural products. The limited number of products made the import value on some economic sectors in Indonesia increased. The softened measures on the economic activity resulted in higher economic value in the agricultural and non-agricultural sectors. Djaganata (2019) predicted that the economic growth in the agricultural sector was reached $1.8 \%$ accompanied by a $6.9 \%$ increase on the worker aspect, and $9.9 \%$ on the other sectors. The agricultural sector expected to be able to anticipate the Covid-19 impact and stabilized the community social-economic status.

The risk mitigation due to the decrease in agricultural field performance could be enhanced by improving the farmer trust. The government and stakeholders must be allocated the resources to the agricultural field to ensure the proper implementation of economic activity in the agricultural field during the Covid-19 outbreak. This step could repressed the poverty and improving the farmer wellness. Some policies and strategy done were: (1) empowering the farmer through "cash-intensive labor" based on agribusiness in rural area with the cash for work model (2) open a job recruitment for the farmer, community with the low level of economic status, and unemployment for the additional salary (3) improving the farmer wellness in rural area, and (4) ensuring the availability and staple food access for the community on the reasonable price.

\section{Agricultural Sector Preparedness in Anticipating and Coping with the Covid- 19 Outbreak}

The national and local stakeholders prepared a sustainable strategy to improve the economic growth in a professional and disciplined method according to the community ability and motivation. The main strategy done was recovering the low level of economic activities by repairing strategic economic entities in the agricultural or non-agricultural fields in rural areas. This condition stimulated the increase of price on the agricultural and non-agricultural sectors. The 
recovery phase of the stagnant economic growth due to the impact of the Covid19 was done through building a broader range of economic activities, especially by actively involving the community in a rural area to participated in the economic transaction and suggested the community in city area (middle-class level) to use e-commerce system in buying their staple food need.

For example, since 5 years ago, the economic growth in the feed mill industry was getting slow and has declined to the present (from the $10 \%$ to $6 \%$ and finally ended in $5 \%$ this year). This percentage indicated that the stagnant economic growth was happening. The food staple business was still running well as represented by the cost of goods manufactured adjusted with the production business scale. Laurence (2020) predicted that the slow economic growth movement in Indonesia reached $4.8 \%$ at the end of 2019 . The impact of Covid-19 would be able to reach the number of -1.35 to $0.15 \%$ in 2020 . Rob et al. (2020) through the regression model predicted that the $1 \%$ decrease of the economic growth, would improve the poverty and staple food insecurity of $2.0 \%$. The stagnant global economic growth caused a drastic drop in the agricultural volume production, hence the cost of goods manufactured increased. The impact of Covid-19 spread on GDP (Gross Domestic Product) and trade-balance shows in Table 1.

Table 1. The Impact of the Spread of Covid-19 on the GDP and Trade Balance

\begin{tabular}{|c|c|c|c|c|c|c|}
\hline \multirow{2}{*}{ Country } & \multicolumn{2}{|c|}{$\begin{array}{c}\text { Labor } \\
\text { Productivity } \\
\text { Scenario } \\
\end{array}$} & \multicolumn{2}{|c|}{$\begin{array}{c}\text { Total Factor of the } \\
\text { Productivity } \\
\text { Scenario } \\
\end{array}$} & \multicolumn{2}{|c|}{$\begin{array}{c}\text { Trade Cost } \\
\text { Scenario }\end{array}$} \\
\hline & $\begin{array}{l}\text { GDP } \\
\text { (\%) }\end{array}$ & $\begin{array}{c}\text { Trade Balance } \\
\text { (US \$ Million) }\end{array}$ & $\begin{array}{l}\text { GDP } \\
\text { (\%) }\end{array}$ & $\begin{array}{l}\text { Trade Balance } \\
\text { (US \$ Million) }\end{array}$ & $\begin{array}{l}\text { GDP } \\
\text { (\%) }\end{array}$ & $\begin{array}{c}\text { Trade } \\
\text { Balance } \\
\text { (US \$ Million) }\end{array}$ \\
\hline Indonesia & $(0.59)$ & $(1,638)$ & $(3.45)$ & $(9,693)$ & $(4,95)$ & $(9,255)$ \\
\hline Singapore & $(0.63)$ & (313) & $(4.58)$ & $(1,153)$ & $(5.01)$ & $(1,781)$ \\
\hline Thailand & $(0.52)$ & $(607)$ & $(4.04)$ & (42) & $(4.95)$ & $(1,689)$ \\
\hline Malaysia & $(0.60)$ & $(234)$ & $(4.79)$ & 1,301 & (4.99) & $(485)$ \\
\hline USA & $(1.00)$ & 37,395 & $(3.10)$ & 140,695 & $(5.03)$ & 174,993 \\
\hline China & $(0.77)$ & $(17,684)$ & $(5.06)$ & $(69,746)$ & $(4.92)$ & $(102,250)$ \\
\hline EU & $(0.81)$ & 3,533 & $(3.47)$ & 48,205 & $(5.04)$ & 36,296 \\
\hline $\begin{array}{l}\text { Other } \\
\text { Country }\end{array}$ & $(0.69)$ & $(20,453)$ & $(3.29)$ & \multicolumn{2}{|c|}{ Country } & $(95,828)$ \\
\hline Source & 1. & (- & 020) & & & \\
\hline Note & $\begin{array}{l}\text { SIM-1 } \\
\text { Produ }\end{array}$ & bor Product & Chor & onori & 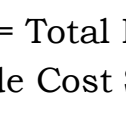 & or \\
\hline
\end{tabular}

The impact of the spread of Covid-19 caused the decrease of agricultural volume production on the SIM-3 and other plant sectors as much as 5.5\%, hence the cost was increasing (Hermanto, 2020). On the opposite side, the staple food export on the SIM-2 and SIM-3 was increasing, respectively with the total value of $2.17 \%$ and $7.14 \%$. The other economic impact was the increase of the staple food export value (0.56\%) on SIM-1 (Hermanto, 2020). The impact of the decrease of production volume on the primary agricultural commodity and the other type 
of commodities was similar. The decrease production of staple food and industry potentially abrupted the other economic activities in all over the world. The impact due to the decrease of the workers was smaller than the productivity and the increase of the trade cost. The role of the agricultural sector was to improve economic growth through the re-development of the manufacture, service, and other sectors.

The recovery phase done based on the policies and some supporting regulations issued by the government in reducing the transmission of Covid-19. As the implication of the action taken, the product produced would be decreased due to the decrease of demand (demand shock) and the disturbed flow of the production supply (supply shock). Comprehensively, the impact of Covid-19 on the economic macro aspect would be presented by the stagnant economic growth and trade balance.

\section{The Staple Food Import Distribution}

The Covid-19 outbreak was started in December 2019 in China and spread to all over the world. This outbreak was becoming the main cause of the high mortality rate and created a stagnant global economic growth. Regulation, policy, and innovation required to support the agricultural industry and other sectors which finally could affect the exchange rate, investment index, and domestic consumption. Covid-19 outbreak also influenced the feed mill, seed, fertilizer, and pesticide industry due to the hindrance of supply, logistics, and the increase of the price. This impact also caused a drastic decrease in production volume (5\%) (Hermanto 2020). The volume production decrease happened in a wide-scale globally, hence the product distribution decrease and import/export price increase. On the decrease human resource scenario (SIM-1) almost all agricultural commodities were experiencing the increase of import price of 3.99-5.35\%, the increase of product price of $0.39 \%$, and the increase of export value of $0.04-0.74 \%$.

On the SIM-2 scenario (the decrease in the productivity factor and the increase of agricultural import value of 4.94\%) and the SIM-3 scenario (the increase of the trade cost), agricultural import volume increase higher than other scenarios, 3.26-7.28\% with the increase of the export volume of $0.2-1.3 \%$. The decrease value on the export and import volume was higher in the nonagricultural sector (Hadiutomo, 2020). Similar situations happened in the staple food industry and non-agricultural sectors. This situation indicated that the efficiency and effectivity of the production factors simultaneously affected all economic sectors in Indonesia. The economic change on the global level also affected the economic growth in Indonesia. The dynamic of those economic scenarios on the agricultural and non-agricultural sectors caused the decrease of workers work performance, improvement of trade cost, and the decrease of volume production.

The decrease of the agricultural export value of $1.2-7.14 \%$ < nonagricultural export value) caused a decrease in household value and increasing the criminal behavior in the community such as panic buying, drug transaction, and robbery. The 11 staple food commodities were coordinated by the national and local stakeholders by actively involving the Directorate General of Food Crop, Directorate General of Animal Husbandry, farmer groups, National Logistical 
Supply Organization, and Indonesian Feedmills Association with mapped food availability in the next 6 months. The prospect of production and staple food need is shown in Table 2 and Table 3.

Table 2. The Availibility of 11 Staple Food Strategic Commodity in the Period of March-August 2020 (the nexth 6 months)

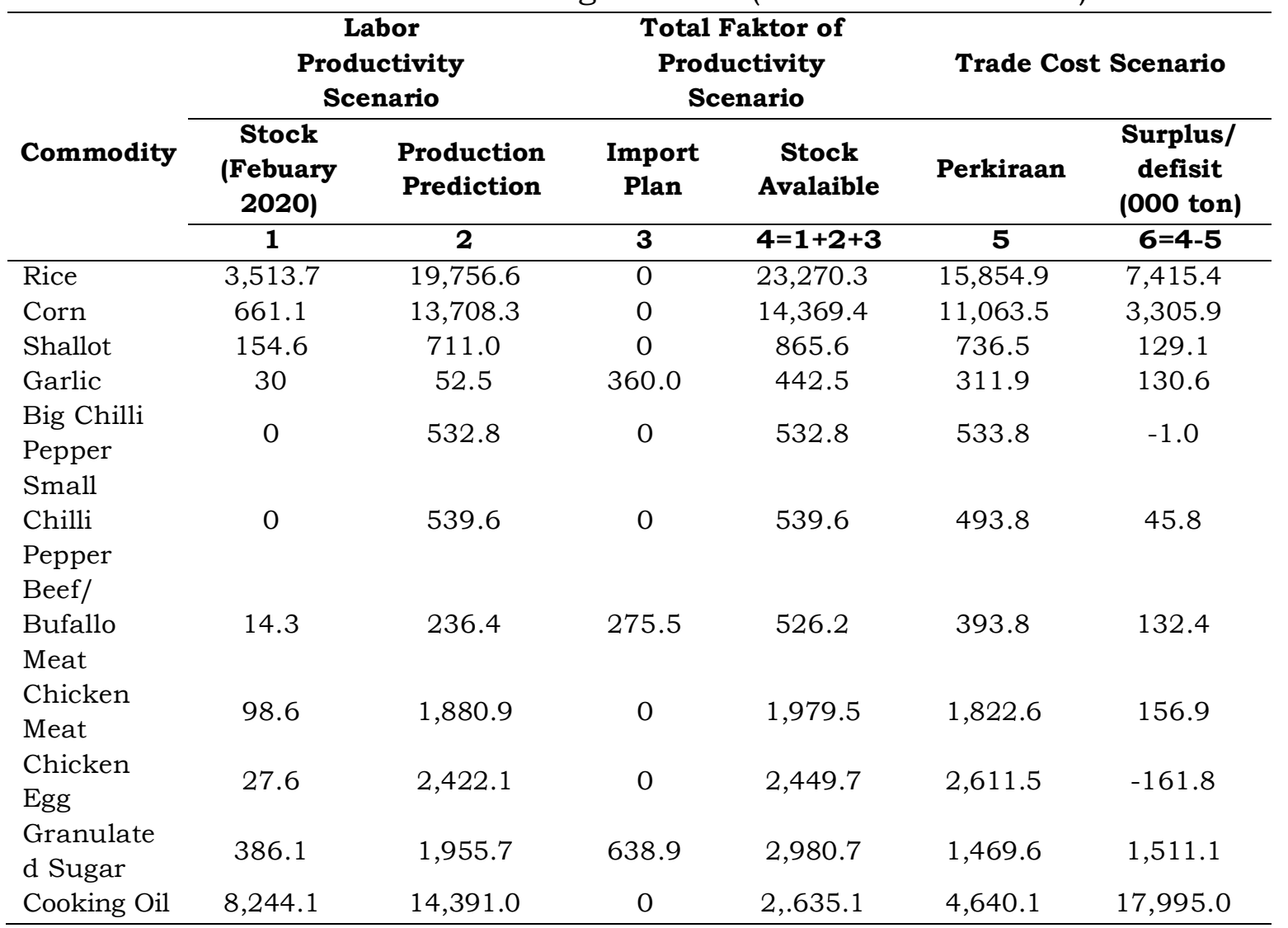

Source: BKP and Indonesian Ministry of Forestry (Hadiutomo, 2020)

Table 3. The Staple Food Commodity Need in the Period of June-August 2020

\begin{tabular}{|c|c|c|c|c|c|c|}
\hline \multirow[b]{2}{*}{ Commodity } & \multicolumn{4}{|c|}{ The Stock Prediction } & \multirow[b]{2}{*}{$\begin{array}{c}\text { The } \\
\text { Prediction } \\
\text { of Staple } \\
\text { Food Need }\end{array}$} & \multirow{2}{*}{$\begin{array}{c}\text { Balance } \\
\text { Prediction } \\
\text { until } \\
\text { August } \\
\text { (Ton) }\end{array}$} \\
\hline & $\begin{array}{c}\text { The Last } \\
\text { Stock on } \\
\text { May } 2020\end{array}$ & $\begin{array}{c}\text { The } \\
\text { Productio } \\
\text { n } \\
\text { Prediction }\end{array}$ & $\begin{array}{c}\text { The } \\
\text { Import } \\
\text { Plan }\end{array}$ & Total & & \\
\hline & $\mathbf{1}$ & 2 & 3 & $4=1+2+3$ & & \\
\hline Rice & $7,775,886$ & $7,965,923$ & & $15,741,809$ & $7,492,056$ & $8,249,753$ \\
\hline Corn & $4,327,545$ & $4,807,119$ & & $9,134,664$ & $4,599,959$ & $4,534,705$ \\
\hline Shallot & 240,523 & 415,146 & & 655,669 & 354,094 & 301,575 \\
\hline Garlic & 116,306 & 14,801 & 34,858 & 131,107 & 146,444 & 15,337 \\
\hline $\begin{array}{l}\text { Big Chilli } \\
\text { Pepper }\end{array}$ & & 294,758 & & 294,758 & 273,713 & 21,045 \\
\hline $\begin{array}{l}\text { Small } \\
\text { Chilli } \\
\text { Pepper }\end{array}$ & & 282,878 & & 282,878 & 251,998 & 30,880 \\
\hline $\begin{array}{l}\text { Beef/Bufal } \\
\text { lo Meat }\end{array}$ & 62,850 & 107,798 & 180,752 & 170,648 & 192,110 & 21,462 \\
\hline Chicken & 204,632 & 992,764 & & $1,197,396$ & 854,604 & 342,792 \\
\hline
\end{tabular}




\begin{tabular}{lccrrc}
$\begin{array}{l}\text { Meat } \\
\text { Chicken }\end{array}$ & 24,906 & $1,268,117$ & $1,293,023$ & $1,203,041$ & 89,982 \\
$\begin{array}{l}\text { Egg } \\
\begin{array}{l}\text { Granulate } \\
\text { d Sugar }\end{array}\end{array}$ & 563,521 & $1,595,571$ & $2,159,092$ & 691,436 & $1,467,656$ \\
Cooking Oil & $12,861,142$ & $8,412,132$ & $21,273,274$ & $2,299,897$ & $18,973,377$ \\
\hline
\end{tabular}

Source: Planning Agency stated in Damanik (2020)

Note:

*Additional Import Agreement required **180,752 tons of beef/bufallo planned to be imported in June-August 2020

Consisted of 143, 135 tons of beef/ buffalo and 150,000 cattle equal to 33,617 beef (Directorate General of Livestock and Animal Health Services, 2019)

The availability and the need of the 11 strategic staple food commodity shows by the Table 2 and 3, from March to August, 2020. All food commodities fairly mapped by considering the product characteristic. The product was seasonal and fluctuating. The stock depending on the market demand. The prediction of the staple food need in the period of March to May 2020 made stated that the food stock would be able to meet the national food demand.

\section{The Impact dan Management of the Strategic Food Staple Availability}

The agricultural sector was strategic and vital in Indonesian economic growth. The staple food availability influenced a wide range of aspects. Indonesia declared as the biggest agricultural country in the world, therefore Indonesia must be well utilized the agricultural resources in this country. The rapid development of the digital technology for the agricultural human resources training, the marketing effort (seed, fertilizer, and agricultural/livestock), infrastructure development, food ingredients from vegetable and animal development, food, and other agricultural product development. The community also suggested improving the agricultural volume production and farmer wellness by appropriately facing the outbreak by praying, working, and studying from home while stay implementing a healthy lifestyle and try to create better food self-sufficiency.

The solution offered by the government side was issuing appropriate policies and steps in the agricultural sector and other supporting sectors in providing farmer organization guidance and training, human resources training, agricultural aid, production input, mapping, providing 11 strategic agricultural commodities, maintaining price stability, ensuring the marketing section, disseminating information about the cheap market, creating a constant agribusiness harvesting production, and reducing the transmission of Covid-19. The solution offered on the consumer side was chosen all staple food needed in the cheap market on the online platform by a cash-on-delivery paying system. This method also categorized as an ideal implementation of the use of masks and social distancing to reduce the spread of Covid-19. The government also already tried its best effort to cope with this outbreak. The community also must be joined in this effort by following the quarantine measures.

Gunawan (2019) introduced the digital technology named KerabaTani that mainly functioned as a reference about the land condition, cultivation schedule, pest attack detection, production cost, maximal profit, quality, and quantity. This was a 
Trigonal Smart Management-based System that bridging the Senbox technology, Ubiquitous Environmental Characteristic System, and Cloud Computing technology. This application also helped the farmer in determining the size of cultivation land and the appropriate climate (Gunawan, 2019). Manager Collective Intelligence Agriculture (CI-Agriculture) Program also provided the technological aid during this outbreak. This program integrated in crowdsourcing manner, therefore the information about current economic growth and staple commodity price from various media were showed in this application. These applications expected to be improved farmer wellness (Kalamullah, 2020). The analysis provided a specific recommendation for the farmer and consumer.

The digital applications helped the management of agricultural volume production and its marketing effort through collaboration between the agricultural and non-agricultural sectors in the commercial context. These explanations indicated that the agricultural sector played a significant role in decreasing the spread of Covid-19 in Indonesia. This sector directly correlated with the community basic need, hence the agricultural volume production couldn't be bothered and must be ensured to be capable reached by all community level. The agricultural sector had a high economic value and highly contributed to prevent the global economic crisis during the Covid-19 outbreak.

\section{The Impact and Management of People's Business Credit (Kredit Usaha Rakyat in Bahasa Indonesia)}

Covid-19 influenced all life sectors, one of them is the agricultural sector. A management offered by the government was utilizing the people's business credit system for the agricultural field (Limpo, 2020). This system has not implemented in the livestock area. This system also equipped with seeds, seedlings, fertilizer, and feed subsidies, also complemented by an acceleration of agricultural product exports. If the agricultural volume production could significantly increase in three consecutive quarters, Indonesia potentially could be placed as the highest staple food exported country. According to the data from the Directorate General of Treasury, Indonesian Ministry of Finance on April 3rd, 2020, 477,447 farmers reached the people's business credit fund in the cooperation and farmer cooperation (avalist). The total of funds allocated for these farmers was IDR 13.5 billion.

The fund allocation (more than IDR 50 billion, with a fixed interest of $6 \%$ ) to improve the agricultural sector work performance supervised by the local stakeholder. The fund was allocated for the staple food cultivation (IDR 3.9 billion), plantation area (IDR 4.1 billion), horticultural area (IDR 1.6 billion), livestock area (IDR 2.7 billion), and other (IDR 1.19 billion). These fund allocation conducted to improve the agricultural volume production, met the staple food demand, and stabilized the national economic growth in 2020. These efforts expected to improve the added value and competition among the farmer, hence the national economic growth could be shifted to the agricultural field as the main source of national income.

\section{The Impact and Its Management on the Cattle Livestock Business}

Indonesia was only able to meet $70 \%$ of its local beef need, the rest of it fulfilled by imported beef and commercial cattle (Directorate General of Livestock and Animal 
Health Services, 2019 dan Rikin, 2018). The national milk demand reached the amount of 4.5 million tons. However, the local milk volume production only covered $19 \%$ or 864,600 tons from the national milk demand (Directorate General of Livestock and Animal Health Services, 2019). This situation made the national government must import a high volume of milk, 3.65 million tons, or cover $81 \%$ of the total consumption (Rikin, 2018). The seeding cattle livestock business didn't utilize forage for the cattle. Each farmer usually had two or three cows in their livestock business. The calves produced in this business usually sold by the farmer to pay their daily need during the Covid-19 outbreak. The Director of Livestock Management and Marketing stated that the maximal number of credit for the micro and small business entity was IDR 25,000,000-50,000,000, with a fixed amount of interest of $7 \%$.

Coordinating Ministry for Economic Affairs stated that the plan could be done according to the president instruction. Corporation between the farmers would help the farmer to run their agribusiness effectively. Article number 37 on the Constitution No. 19 Year 2013 about Farmer Protection and Employment stated that the government should protect the agribusiness from the loss due to the crop failure by using an insurance system. Unfortunately, this insurance didn't cover all cattle farmers in Indonesia. The insurance only given to the fattening and seeding cattle livestock owner (with the minimal number of cattle registered to the insurance of four cattle in the range of 8 months to four years/cattle livestock owner/cooperative). To receive this insurance, each cattle livestock farmer must actively participate in a livestock farmer group with a complete organizational structure.

The beef cattle farmer should be able to implement the good farming practices and good breeding practices. The national government must be allocated IDR 19.2 billion for the cattle insurance cost (Syahroni, 2020). Due to the lack of the cattle food quality and quantity, Indonesia still couldn't able to reach the beef selfsufficiency. To deal with this situation, the farmer developed a food fermentation technology, supplementation, barn feed, and food preservation in a form of silase and Hay. A close relationship between the farmer and academics provided the farmer chance to obtain science based-technical guidance related to the method to improve the beef production. Some agricultural and animal husbandry students also placed in their livestock farming to learn about the real agricultural cases. The common hindrances in developing this business were the limitation in producing the cattle food and human resources in managing the business. The fluctuating selling price was also highly contributed to the stagnant growth of this business.

\section{The Impact and Management of the Big Data Implementation as the Public Policy}

Rapid-evolving technology devices made the Covid-19 outbreak situation and its impact possible to be monitored in a real-time context. Big-data served the community mobility data and commercial agricultural sector quality in domestic and international range (Kalamullah, 2020). Big Data Analytics technology or metaanalysis didn't widely use by farmers in rural areas. The lack of knowledge and skill was the main reason for the low usage of this technology. Big data provided various benefits for the farmer. Big data developed the agricultural product to be widely used, hence the agricultural productivity and efficiency could be improved. 
Bambang (2017) stated that information and communication technology have been becoming a part of the community life, economic activity, economic, political, and social development, and contributed to the policy formulation of the agricultural and non-agricultural policies. The Big Data used is becoming a trend in formulated specific policies and planning a development on the agricultural or non-agricultural sector. Food and Agriculture Organization (FAO) used the Big Data Synthesis to develop a water global information system. Tiongkok Big data used to map the poverty by employing the Call Data Records that provided sustainable poverty data and percentage. Nepal also used handphone data to map the population movement in their country. While Haiti used a group of data from the volunteers to analyze the information on the online platform (Facebook, Twitter, and short message service) to deliver emergency care after the earthquake (Indonesian Ministry of National Development Planning, 2017). Currently, Indonesia is using Big Data to help the government in public decision making, formulated policies, and as references to the monitoring and evaluation activity.

Indonesian Ministry of National Development Planning already used Big Data as the reference in making policies, recommendations, and formulation of agricultural development. During the Covid-19 outbreak, Big Data used to monitor the real-time condition, hence the public could obtain accurate data about the current situation. Each representative area must be monitored the situation during the Covid-19 outbreak by using Big Data. The dynamic of the agricultural activity also could be tracked by the Big Data. Indonesian Ministry of National Development Planning cooperated with the Global Pulse Lab Jakarta used Big Data with staple food price nowcasting projection by utilizing the social media signals.

Big Data had a good accuracy in monitoring and detecting the impact of Covid19, therefore better policies could be produced by the data provided on this system. The stakeholder suggested to be supported the use of Big Data as the complement of the traditional and international data. Big Data could be accompanied by the collaboration between the institution (government, academics, and industry) to provide higher data accuracy in comprehensive, detail, on time, and precise form of decision making.

Today, the digital revolution era already touched all aspects of life. Many forms of digital form-activities produced massive and various types of data in a fast manner (real-time) (Erwin, 2018). All system that worked under this type of system named Big Data. The proper management of data could produce high-quality information or knowledge to manage the economic activity. The national stakeholder or policymaker suggested to be able to utilize Big Data to take proper action in managing the public issues. Big Data must be supported by the access to certain data sources. The accessibility of Big Data often got crashed by some law and private aspect. To cope with this problem, all institutions (governmental or non-governmental) must be worked together in building a data access mechanism. This mechanism would be provided access and permission between the data owner and national authority in producing quality, productive, effective, and safe policies to accelerate the agricultural/non-agricultural economic growth. 


\section{The Impact and Strategy Required for the Market Development}

The national policies during the Covid-19 outbreak made according to the staple food marketing scenarios. Covid-19 outbreak measures stated that all traditional markets must stop operating to reduce the viral transmission. Limpo (2020) stated that in coping with the uncertainties during the Covid-19 outbreak, the market must be played its role as the bridging point between the farmer and the consumer to control the product prices. The online taxi bike also utilized this situation by serving the economic transaction extensively (providing cheap delivery price and cash-on-delivery system). Rohmani (2020) stated that food security maintained by using some market scenarios. The national staple food demand must be able to be fulfilled sustainably. Concrete steps must be done to complete this goal.

The national staple food demand during the Covid-19 outbreak could be met by some active participation of the market operation, online taxi bike, inexpensive market, and small-agribusiness entity. The cash intensive-labor effort (padat karyatunai in Bahasa Indonesia) and the improvement of the community purchasing-power opened a broader chance for the online taxi bike and freelance workers to increase their income. The development of marketing technology affected the link between the farmer and consumer, also between the farmer to processor to consumers, continuously. Then the policies arranged would support the sustainable agricultural modernization effort. The intermediate-term policies implemented by creating policies that strengthen the agricultural production volume and promoting the farmer/consumer behavior change (Juaningsih et al. 2020). In the long-term period, these policies expected to be able to strengthen the food and agricultural sector security by keep adapting to future challenges. Hence, the sustainable economic growth could be accomplished.

A capital aid for the production process, improvement of the farmer skill, and involvement of the millennial generation urgently required to the proper market development. A comprehensive understanding of the behavior change through the information dissemination about the importance of multi-channel marketing and health promotion to implement a healthy lifestyle and healthy food would be helped the community to cope with this outbreak. The policies arranged also must be supported by the development of agricultural marketing techniques in improving the link between the farmer and consumer. In the longterm context, the national stakeholder or policymaker must be disseminated comprehensive information to improve the national community understanding of the urgency of the behavior change on the farmer wellness aspect. The national program arranged must be encouraging the synergy and acceleration in strengthening the sustainable agricultural modernization strategy, strengthening the national food security, and stabilizing the agricultural sector during the Covid-19 outbreak and in the future. The number of consumer food purchasing and spending shows in Figure 1. 


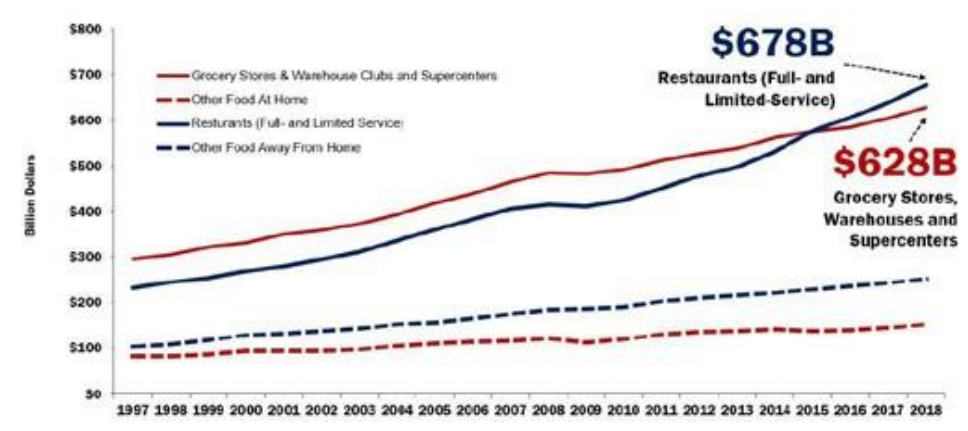

Figure 1. Consumer Food Purchasing and Spending Graphic Source: USDA Farm Biro Calculation as stated in Rohmani (2020)

\section{CONCLUSION}

Through the various policies in health and economic aspects, the Covid-19 outbreak and its negative impact on the national community level expected to be ended in the period of July-December 2020. The strategies offered to manage the stagnant economic growth in the agricultural sector was ensuring the availability of the staple food product, strengthening the village economic endurance, and improving the community purchasing power through the development of the marketing scenarios and enhancement of the marketing technology policies. These strategies' goals were to encourage the farmers to processor to consumers and farmers to consumers process, enhancing the market process, providing social aid for the household parties, providing intensive-labor capital (cash form), and improving the number and quality of the agricultural resources (especially on the millennial generation).

\section{IMPLICATION}

The strategy required to manage the stagnant economic growth in the agricultural aspect during the outbreak was the synchronization between the longterm policies and the dynamic of Covid-19 spread. This strategy would strengthen the food and agricultural security, helped the development of the advanced data use system (true and most recent data is updated immediately), encouraged sustainable agricultural modernization, and ensured the sustainable economic growth during the Covid-19 outbreak now and in the future.

\section{REFERENCES}

Ajiyanto, R. 2020. Peternak Ayam 'Babak Belur' Dihantam Dampak Corona Ragil https: / finance.detik.com/berita-ekonomi-bisnis/d-4979469/peternakayam-babak-belur-dihantam-dampak-corona (diakses tgl, 8 Juni 2020)

Atbubone, B. F. 2020. Wabah Corona Belum Mempengaruhi Kenaikan Harga Sapi di Indonesia Sumber: https://mediaindonesia.com/read/detail/311926dampak-Covid-19-penjual-daging-sapi-di-klaten-tiarap 
Baldwin, R., Weder \& Mauro, B. 2020. Economics in The Time of Covid-19. A. VoxEU. org Book. CEPR Press. Centre for Economic Policy Research. Great Sutton Street London, EC1V ODX. UK

Bambang. 2017. Implementasi Big Data Untuk Perumusan Kebijakan Publik, https: / / www.bappenas.go.id/id/berita-dan-siaran-pers/implementasi-bigdata-untuk-perumusan-kebijakan-publik/February 21st, 2017 4:30 pm (di akses tgl, 10 Juni 2020)

Byrne, J. 2020. Covid-19: EUdairy and beef sectors suffering under food service sector closure. https://www.feednavigator.com/Article/2020/04/08/Foodservice-closure-hits-EU-dairy-and-beef-sectors.

Dadang. 2020. Pemerintah Umumkan Stimulus Ekonomi Kedua untuk Menangani Dampak Covid-19 dadag - Jumat, 13 Maret 2020 12:14, https: / / pasardana.id/news/2020/3/13/artikel/pemerintah-umumkanstimulus-ekonomi-kedua-untuk-menangani-dampak-Covid-19/ (diakses tgl, 8 Juni 2020)

Damanik, R. S. 2020. Membangun sinergitas lintas sektor dalam menghadapi Covid-19, terhadap sektor pertanian. Buletin Perencanaan Pertanian. Kementerian Pertanian Jakarta. 1(2):28-40

Dinas Perikanan dan Peternakan Kabupaten Tuban.2020. Pelatihan pembuatan sediaan biofarmaka untuk sapi potong sebagai solusi alternatif untuk menekan biaya produksi pakan dan obat-obatan dalam usaha peternakan https://diskannak.tubankab.go.id/entry/artikel/pelatihan-pembuatansediaan-biofarmaka- (diakss tgk, 8 Juni 2020)

Djaganata, A. N. 2019. Akselerasi investasi pemerintah dorong investor peternakan, Selamat datang di website resmi Dinas Peternakan dan Kesehatan Hewan Provinsi NTB. https://disnakkeswan.ntbprov.go.id/artikel/akselerasiinvestasi-pemerintah-dorong-investor-peternakan/ (diakses tgl, 6 Juni 2020)

Djufry, F. 2020. Rencana Strategis Badan Penelitian dan Pengembangan Pertanian Tahun 2020 -2024. Badan Penelitian dan Pengembangan Pertanian, Jakarta. Paper dipresentasikan pada Tanggal 11 Juni 2020 di Jakarta.

Erwin. 2018. Pemanfaatan Big Data Optimalikan Perumusan Kebijakan http: / /infopublik.id/kategori/ekonomi-

bisnis/artikel/artikel282646/pemanfaatan-big-data-optimalikanperumusan-kebijaka/ (diakses tgl 10 Juni 2020).

Fajar, T. 2020. Dampak Covid-19, KUR Pertanian Dapat Relaksasi Pembayaran, https://economy.okezone.com/read/artikel/2020/04/13/320/2198579/da mpak/artike-Covid-19-kur-pertanian-dapat-relaksasi-pembayaran (diakses tgl, 6 Juni 220)

Felippa, A. \& Ira, A. 2020. [Policy Brief] Indonesian Food Trade Policy during Covid19, Updated: May 5. https://www.cips-indonesia.org/post/policy-briefindonesian-food-trade-policy-during-Covid-19. (diakses tgl, 12 Juni 2020) 
Gunawan, A. 2019. Inovasi Pertanian Indonesia Melalui Big-Data Agriculture, https://www.goodnewsfromindonesia.id/2019/06/10/artikel/mahasiswa Malang/ inovasi-pertanian-indonesia www.kerabatani.com atau media sosial Instagram@kerabatani.id. kerabataniindonesia@gmail.com, (diakses tgl, 9 Juni 2020)

Hanoatubun, S. (2020). Dampak Covid-19 terhadap Prekonomian Indonesia.EduPsyCouns: Journal of Education, Psychology and Counseling,2(1), 146-153.

Hermanto. 2020. Dampak ekonomi penyebaran Covid-19 terhadap kinerja sektor pertania. Biro Perencanaan Kementerian Pertanian Buletin Perencanaan Pertanian. Dampak Covid-19 terhadap sektor pertanian.1(2):7-17.

Hadiutomo, K. 2020. Kebijakan pertanian untuk menangani dampak Covid-19, Perencana Ahli Utama Biro Perencanaan, Kementerian Pertanian Buletin Perencanaan Pertanian. Dampak Covid-19 terhadap sektor pertanian.1(2):1827.

Iim, F. T. 2020. Integrasi Kebun Sawit dan Peternakan Sapi Belum Efektif https://ekonomi.bisnis.com/read/20190911/99/1146932/jurnal/integrasikebun-sawit-dan-peternakan-sapi-belum-efektif (diakses tgl, 9 Juni 2020)

Johns Hopkins CSSE 2020. Johns Hopkins CSSE Note: The CSSE states that its numbers rely upon publicly available data from multiple sources, which do not always agree

https://www.theguardian.com/world/2020/jun/11/coronavirus-worldmap-which-countries, (diakses tgl, 15 Juni 2020)

Juaningsih, I. N., Consuello, Y., Tarmidzi, A \& NurIrfan, D. (2020). Optimalisasi Kebijakan Pemerintah dalam penanganan Covid-19 terhadap Masyarakat Indonesia.SALAM: Jurnal Sosial dan Budaya Syar-i,7(6).

Kalamullah, H. 2020. Implementasi Big Data sebagai Perumusan Kebijakan Publik https://dailysocial.id/post/ci-agriculture-manfaatkan-teknologi-big-dataanalytics-untuk-bantu-tingkatkan-produktivitas-pertanian (di akses tgl 10 Juni 2020)

Kementerian Perencanaan Pembangunan Nasional.2017. Menggunakan Big data sebagai acuan bagi analisis kebijakan, penyediaan rekomendasi kebijakan, Badan Perencanaan Pembangunan Nasional (BAPPENAS), Copyright (C) 2020 Kementerian PPN / Bappenas All Rights Reserved, https: / / www.bappenas.go.id/id/berita-dan-siaran-pers/implementasi-bigdata-untuk-perumusan-kebijakan-publik/ (diakses tgl, 10 Juni 2020)

Kementerian Pertanian Republik Indonesia. 2020. Informasi terkini mengenai kebijakan Kementerian Pertanian dalam merespon Covid-19 serta tetap menjaga ketersediaan Pangan bagi seluruh rakyat Indonesia, https: / / www.pertanian.go.id/home/?show=page\&act=view\&id=99, (diakss rgl, 11 Juni 2020) 
Laurence B. 2020. Coronavirus: The world economy at risk. The Organisation for Economic Co-operation and Development (OECD).

Limpo, S. Y. 2020. Kementan : KUR Pertanian Diharapkan Bisa Tangkal DampakCovid-19 https: / /www.suara.com/bisnis/2020/04/09/111055/kementan-kurpertanian-diharapkan-bisa-tangkal-dampak-Covid-19 (diakses tgl, 10 Juni 2020)

Mahardhika, W. A. 2020 Pertumbuhan Ekonomi Indonesia di 2020 Berpotensi Meningkathttps://money.kompas.com/read/2020//artikel/pertumbuhan/e konomi-indonesia-di-2020-berpotensi-meningkatKompas.com-07/02/2020, 20:53 WIB. (diakses tgl, 10 Juni 2020)

Mardiyah, R. A. \& Nurwati, R.N. 2020. pandemik Covid-19terhadap peningkatan angka pengangguran di indonesiaoleh, Jurnal abdi masyarakat, LPPM Universitas Pamulang, Jurnal Humanis, 1(2):16-28

McGhee, R. 2020. Beef producers face 'long-term uncertainty' as coronavirus hits export market, but domestic demand surges. ABC Capricornia. Posted 24 May 2020, updated 24 May 2020.https://www.abc.net.au/ news/2020-05-24 / beef-industry-uncertain-times-as-coronavirus-impactssector / 12279442

Nidya, I. R. 2020. Tangkal Dampak Covid-19 pada Pertanian, Mentan Ajak Petani Manfaatkan KUR/https://money.kompas.com/artikel/read/2020/04/ 09/132441626/artikel/tangkal-dampak-Covid-19-pada-pertanian-mentanajak-petani-manfaatkan-kur, (diakses tgl, 14 Juni 2020).

Nursyamsi, D. 2020. Kementerian Pertanian. 2020. Hadapi wabah Covid-19, Kementan atur strategi pangan, Badan Penyuluhan dan Pengembangan SDM Pertanian (BPPSDMP) jumpa pers di Kantor Pusat Kementan https: / / www.liputan6.com/ bisnis/read/4205268/hadapi-wabah-Covid-19kementan-atur-strategi-pangan (diakses tgl, 8 Juni 2020)

Ozili, P. K., \& Arun, T. (2020). Spillover of Covid-19: impact on the Global Economy.Available at SSRN 3562570.Stratton, S. J. (2020). Covid-19: Not a simple public health emergency.Prehospital and Disaster Medicine,35(2), 119119.

Pusat Penelitian dan Pengembangan Perkebunan. 2020. Covid-19: Peluang dan Dampak Terhadap Sektor Pertanian http:/ / perkebunan.litbang.pertanian.go.id/Covid-19/artikel-peluangdan-dampak-terhadap-sektor-pertanian/ artikel. (diakss tgk 5 Juni 2020) Hak Cipta 2017 | Email : puslitbangbun@litbang.pertanian.go.id

Rahma, A. M. \& Nurwati, R.N. 2020. Ilmu Kesejahteraan Sosial, Fakultas Ilmu Sosial dan Ilmu Politik, Universitas Padjadjaran ${ }^{1}$ rahma18005@mail.unpad.ac.id,nngnurwati@yahoo.co.id, https://d1wqtxts 1xzle/Artikel/loudfront.net, (diakses tgl 14 Juni 2020) 
Raofiq, M. 2020. Dampak Covid-19 bagi Peternak Sapi dan Solusinya dengan Biogas https://www./artikelkompasiana.com/mohtaufiq4729/5ea406b5097f36244 6452804/dampak-Covid-19-bagi-peternak-sapi-dan-solusinya-denganbiogas, (diakses tgl, 13 Juni 2020)

Rikin, A. S. 2018. Teknologi Fermentasi Jadi Solusi Pakan Sapi, Sumber: Suara Pembaruan,https: / /www.beritasatu.com/nasional/505296-teknologifermentasi-jadi-solusi-pakan-sapi (diakses tgl,14 Juni 2020)

Rob, V., Martin, W. \& Laborde, D. 2020. How much will global poverty increase because of Covid-19?. International Food Policy Research Institute (IFPRI).

Rohmani, S. A. 2020. Implikasi Covid-19 bagi upaya pemenuhan kebutuhan pangan. Perencana Ahli Madya Badan Litbang Pertanian. Buletin Perencanaan Pertanian. Dampak Covid-19 terhadap sektor pertanian, 1(2)4255

Rosmayati dan Aprilio. 2020. Permintaan dan priortas pangan hasil pertanian https://www.wartaekonomi.co.id/artik/1read277648/hadapi-Covid-19-dprminta-pemerintah-prioritaskan-sektor-pertanian, (diakses tgl, 4 Juni 2020)

Sardjono, D. 2020. Dampak Covid-19, Penjual Daging Sapi di Klaten Tiarap Sumber: https://mediaindonesia.com/artikel/read/detail/311926-dampak-Covid-

19-penjual-daging-sapi-di-klaten-tiarap/artikel_lengkapnya baca di majalah Trobos Livestock Edisi 247 / April 2020, (diakses tgk, 4 Juni 2020)

Sohrabi, C., Alsafi, Z., O’Neill, N., Khan, M., Kerwan, A., Al-Jabir, A., \& Agha, R. (2020). World Health Organization declares global emergency: A review of the 2019 novel coronavirus (Covide-19). International Journal of Surgery.

Sugiono. 2020. Persepsi Bahas Dampak Covid-19 di Sektor Peternakan, https: / /anggam.id/persepsi-bahas-dampak-Covid-19-di-sektorpeternakan/ (diakses tgk, 8 Juni 2020)

Suhariyanto. 2020. Pertumbuhan ekonomi Indonesia kuartal I 2020 sebesar 2,97\%/https://nasional.kontan.co.id/news/pertumbuhan-ekonomiindonesia-kuartal-i-2020-sebesar-297, (diakses tgl, 10 Juni 2020)

Susanti, I. 2020. Kajian IPB : Stimulus Ekonomi Kunci Solusi Dampak Covid-19, https://ekbis.sindonews.com/read/61135/34/artikel/kajian-ipb-stimulusekonomi-kunci-solusi-dampak-Covid-19-1591477594, (diakses tgl, 14 Juni 2020)

Syahroni . 2020. Berikut Ini 6 Dampak Covid-19 yang Mungkin Terjadi Pada Sektor Pertanian, https://news.trub Trubus News/us.id/baca/35856/berikut-ini6-dampak-Covid-19-yang-mungkin-terjadi-pada-sektor-pertanian, 17 Mar 2020 21:00 WIB

Taufik, F, Pembelian Pangan Dibatasi, Aprindo Ikut Mengawasi economy.okezone. com, 18 Maret 2020 
Universitas Gadjah Mada. 2020. Mitigasi Penyebaran Corona Virus (Covid-19) dengan Big Data, Lab Riset Sistem Komputer dan Jaringan, Departemen Ilmu Komputer dan Elektronika, FMIPA UGM, https://mipa.ugm.ac.id/2020/03/mitigasi-penyebaran-corona-virusCovid-19-dengan-big-data (diakses tgl 10 Juni 2020)

Vadhia, L. - detikFinanc. 2020. Kemendag Sebut Harga Daging Sapi Stabil Sepanjang 2020 https://finance.detik.com/berita-ekonomi-bisnis/d5022320/kemendag-sebut-harga-daging-sapi-stabil-sepanjang-2020 (diakses tgl, 9 Juni 2020)

Weningtyas, O. G. 2020. Asuransi Untuk Hewan Ternak Sapi, dan Bagaimana Cara Kerjanya. 20, April, 2020/https://www./artikel/cekaja.com/produkasuransi / news / 171569-asuransi-untuk-hewan-ternak-sapi-danbagaimana-cara-kerjanya.html, (diakss tgl, 15 Juni 2020)

World Travel and Tourism Council (WTTC). 2020. Coronavirus puts up to 50 million Travel and Tourism jobs at risk. https://www.wttc. org/about/media-centre/press-releases/press- releases/2020/coronavirusputs-up-to-50- million-travel-and-tourism-jobs-at-risk-says- wttc/. (diakses 6 Juni 2020). 